\title{
Hill country farm investment options - cocksfoot pasture vs. superphosphate fertiliser
}

\author{
D.J. BARKER, D.G. SHEPPARD ${ }^{1}$, A.D. MACKAY and N. DYMOCK \\ AgResearch, Private Bag 11008, Palmerston North \\ ${ }^{1}$ Agriculture New Zealand, PO Box 288, Dannevirke
}

\begin{abstract}
Farmers can choose between investment in pasture species or fertiliser, however, there are few comparisons of these options. This paper reports on the effects of 'Grasslands Wana' cocksfoot, (Dactylis glomerata L.) introduction and superphosphate application on pasture production in hill country. The effects of pasture production on bullbeef production were subsequently modelled using Stockpol ${ }^{\circledR}$. Pasture, bull and financial performance was measured within four self-contained farmlets (each approximately $9 \mathrm{ha}$ ) at the AgResearch Ballantrae Hill Country Research Station; half of two farmlets had been oversown with Wana in autumn 1992 and two farmlets were untreated "Resident" hill pasture. The Wana farmlets generated an average \$42.80/ha greater income than Resident farmlets. On average, modelling with Stockpol found gross financial return was increased by $80 \%$ by application of $40 \mathrm{kgP} / \mathrm{ha}(\$ 715.26 / \mathrm{ha})$ compared to nil fertiliser ( $\$ 397.84 / \mathrm{ha})$. With a cost of fertiliser of $\$ 2.44 / \mathrm{kgP}$ applied $(\$ 97.60)$ this predicted return was highly profitable. If the establishment costs of Wana were spread over the life of the pasture economic responses would be greater from investment in Wana cocksfoot, however, in the short term, economic responses were greater from investment in fertiliser. In the medium term a combination of investment in Wana establishment and fertiliser input would likely maximise the economic return.
\end{abstract}

Keywords: bull beef, Dactylis glomerata L., farm system, 'Grasslands Wana' cocksfoot, Stockpol ${ }^{\circledR}$, superphosphate

\section{Introduction}

Among the options for farm investment are pasture species introduction and fertiliser application. Parminter (1991) modelled the economic return from capital fertiliser application or 'Grasslands Wana' cocksfoot (Dactylis glomerata) introduction, and found a similar payback period (7-8 years) for both investment options. Detailed comparison between these investment options in hill country, however, is complicated by there being relatively little biological information on the relative differences in the responses of pasture and animal production to these farm inputs.

Wana cocksfoot is particularly productive and persistent on sunny aspects in low to moderate fertility hill country. Pasture yield responses of up to $40 \%$ greater than resident pastures have been reported for Wana introduction (Barker et al. 1985, 1993). Webby et al. (1990) calculated that greater production from Wana cocksfoot in hill country could be worth up to $\$ 125 /$ ha, but concluded however, that establishment failure and inconsistent responses of other pasture species made wide-spread use of new pastures in hill country of questionable value. Previous modelling with Stockpol ${ }^{\circledR}$ has found that where establishment of Wana increased total pasture production, increased animal and financial performance can be expected (Parminter 1991; Barker \& Baars 1993), however, no system trials have been done to show the benefits for animal production.

In contrast to pasture species performance, animal responses to fertiliser application in hill country have been shown at a system scale (Lambert et al. 1983; Clark et al. 1986). Responses to superphosphate vary but include 44, 55, $78 \& 91 \mathrm{kgDM} / \mathrm{kgP}$ (Ledgard et al. 1992; Gillingham et al. 1990; O'Connor et al. 1990; Lambert et al. 1983, respectively). Barker et al. (1993) found in dry Wairarapa hill country that Wana had a greater annual yield response $(+39 \%)$ to fertiliser (50 $\mathrm{kgN} / \mathrm{ha}$ and $34 \mathrm{kgP} / \mathrm{ha}$ ) than four other species, suggesting a positive interaction of cocksfoot and fertiliser use might benefit animal production.

Stockpol is a farm system model that allows the effects of variations in farming enterprise and farm inputs on animal performance and farm profitability to be predicted (Marshall 1991). Stockpol is a useful tool for predicting animal and financial responses in lieu of having to complete farm-scale experimentation.

This paper reports on a trial which tested the hypotheses that (a) introducing a more productive grass species (Wana cocksfoot) would increase animal (bullbeef) production in hill country, and (b) this introduction was cost-effective compared to the return expected (through modelling with Stockpol) from investment in phosphate fertiliser application. 


\section{Methods}

\section{Site, trial design and treatments}

Two self-contained farmlets (each approximately 9 ha) had the north- and west-facing slopes (about $50 \%$ of farmlet area) aerially oversown with lime-coated Wana cocksfoot $(22 \mathrm{~kg} / \mathrm{ha}$ ) following defoliation with $2 \mathrm{~L} / \mathrm{ha}$ glyphosate, at the AgResearch Ballantrae Hill Country Research Station in autumn 1992. By 1995 the Wana pastures had an average contribution to yield of 15 $45 \%$ from cocksfoot and 12\% from white clover (Trifolium repens). Another two farmlets were untreated "Resident" hill pasture, comprising browntop (Agrostis capillaris)-dominant pasture with an average 15\% contribution of white clover to pasture yield. The soil was dominantly a Taihape steepland soil, a yellowgrey earth and yellow brown earth intergrade derived from sandy siltstone (Pallic Orthic Brown Soil, Typic Eutrochrept) (J.D. Cowie and R.H Wilde pers. comm.). The trial area had been fertilised with $150 \mathrm{~kg} \mathrm{DAP} / \mathrm{ha}$ for 5 years, and had an initial Olsen P status of $15 \mu \mathrm{gP} / \mathrm{g}$ soil. Long-term rainfall was $1200 \mathrm{~mm} / \mathrm{year}$, and was drier than average during winter 1997 and autumn 1999.

A paddock-scale fertiliser trial was initiated within the grazing trial in June 1997. Three levels of $\mathrm{P}(0,20$ $\& 40 \mathrm{kgP} / \mathrm{ha}$ as superphosphate, 0-9-0-12) were applied in replicate to six 0.5 ha paddocks within each farmlet, i.e., 24 paddocks in total. The high $\mathrm{P}$ treatment (P40) also received an initial capital dressing of $60 \mathrm{kgP} / \mathrm{ha}$ in June 1997. Within each farmlet, the bull grazing rotation was always in order of increasing fertility. There was an additional paddock of each of $\mathrm{P} 0$ and $\mathrm{P} 40$ to remove effects of nutrient transfer, but no measurements are reported from these paddocks. Within each farmlet, since the bulls grazed all fertiliser treatments during their grazing rotation, animal growth could be not ascribed to specific fertiliser treatment. Areas outside the fertiliser trial continued to receive DAP-13S (13$16-0-13)$ at $150 \mathrm{~kg} / \mathrm{ha} / \mathrm{yr}$.

\section{Animal management}

The farmlets were stocked with weaned cross-bred bulls of mixed beef breeds in autumn each year and rotationally grazed within their respective farmlets for up to 10 months, when they were sold for slaughter at approximately $500 \mathrm{~kg}$. Grazing was prescribed by experienced bull farmers affiliated with the trial; the stocking rate and grazing management aimed to ensure pasture mass did not exceed $2300 \mathrm{kgDM} / \mathrm{ha}(2600$ $\mathrm{kgDM} / \mathrm{ha}$ in summer). Sheep were added to each farmlet to control surplus pasture (usually starting in December), to simulate the increased animal demand that occurs in a traditional breeding system. Sheep were also added to each farmlet as bulls were removed for slaughter (usually in January and February), to ensure continuity of grazing and to control ragwort. Sheep and cows grazed the farmlets once bulls were sold for slaughter (usually during March) to 'clean-up' pasture before the next season bulls. Bull drenching and mineral supplementation was according to accepted farm practice.

\section{Measurements}

Pasture growth rate was measured from two pre-trimmed $0.5 \mathrm{~m}^{2}$ exclosure cages per paddock between June 1997 and May 1999 (48 cages in total), cutting when pasture reached an average $2500 \mathrm{kgDM} / \mathrm{ha}$. Seasonal yield was calculated by apportioning harvests on an average daily gain basis to 3 -month periods, with autumn $=$ March May. Pasture composition was measured by manual dissection of subsamples from each harvest. Unfasted bull liveweight was measured each month during 199798. Slaughter data and financial returns were provided by the freezing works in autumn 1998. Other stock were valued in proportion to their grazing period at a gross margin of $\$ 35 /$ stock unit $/ \mathrm{yr}$.

\section{Statistical analysis}

Pasture growth rate data were analysed as a split plot design, with two replicates of two pasture-types (Wana, Resident) as main plots, and three levels of phosphate $(0,20 \& 40 \mathrm{kgP} / \mathrm{ha})$ as sub-plots (paddocks). Seasonal growth calculations were transformed $\left(\mathrm{x}^{1 / 2}\right)$ before analysis of variance using the Statistical Analysis System (SAS) and back-transformed means are presented in Table 1.

Table 1 Mean seasonal and annual pasture yield for 1997-99, for two pasture types and three phosphate treatments, under bull grazing in hill country (3-month seasons; autumn = March-May).

\begin{tabular}{lccccc}
\hline Treatment & autumn & winter & spring & summer & total \\
\hline Resident & 1310 & 1480 & 3270 & 1210 & 7350 \\
Wana & 1650 & 2070 & 4400 & 1440 & 9600 \\
& $+26 \%$ & $+40 \%$ & $+35 \%$ & $+19 \%$ & $+31 \%$ \\
Pr>F & $\mathrm{ns}^{1}$ & 0.055 & 0.032 & $\mathrm{~ns}$ & 0.002 \\
no phosphate & 1330 & 1430 & 3560 & 1250 & 7620 \\
$20 \mathrm{kgP} / \mathrm{ha} / \mathrm{yr}$ & 1320 & 1740 & 3760 & 1210 & 8090 \\
$40 \mathrm{kgP} / \mathrm{ha} / \mathrm{yr}$ & 1800 & 2150 & 4130 & 1520 & 9660 \\
& $+36 \%$ & $+50 \%$ & $+16 \%$ & $+22 \%$ & $+27 \%$ \\
Pr $>\mathrm{F}$ & 0.077 & 0.012 & $\mathrm{~ns}$ & 0.052 & 0.013 \\
\hline
\end{tabular}

${ }^{1} \mathrm{Pr}>\mathrm{F}$ exceeded 0.1

\section{Modelling}

Modelling was completed in two phases using the farm system programme Stockpol (Marshall 1991).

In the first (validation) phase, use of Stockpol was validated using actual pasture and bull growth measured 
during 1997-98 to achieve a feasible (as defined by Stockpol) result for the Resident and Wana farmlets. Model assumptions matched actual practise as closely as possible. Weaned $270 \mathrm{~kg}$ cross-bred bulls were purchased in May, grown for 9 months and sold for slaughter at $530 \mathrm{~kg}$ liveweight (Figure 1). After February, all remaining bulls were sold, those above $450 \mathrm{~kg}$ sold for slaughter and those below $450 \mathrm{~kg}$ sold store. Prices modelled were the schedule prices paid during January and February 1998 (\$1.95-\$2.40/kg carcass-weight). The model assumed 100 ha farms, with the Wana farmlets stocked with 212 bulls and 1500 ewes during autumn, and the Resident farmlets stocked with 201 bulls and 1200 ewes during autumn.

The second (prediction) phase modelled 4 hypothetical farms (Wana-no phosphate, Wana- $40 \mathrm{kgP} / \mathrm{ha}$, Resident-no phosphate, Resident- $40 \mathrm{kgP} / \mathrm{ha}$ ) using the same model assumptions as for the validation phase (above). The number of bulls and sheep was predicted from pasture growth measured within the fertiliser trial (Table 2) (assuming similar pasture cover as during the validation phase), using the "modify" option of Stockpol.

Table 2 Pasture growth rate $(\mathrm{kgDM} / \mathrm{ha} / \mathrm{d})$ calculated from measured production, and total annual yield (kgDM/ha) used for modelling with Stockpol.

\begin{tabular}{lcccc}
\hline Month & $\begin{array}{c}\text { Resident } \\
\text { No P }\end{array}$ & $\begin{array}{c}\text { Wana } \\
\text { No P }\end{array}$ & $\begin{array}{c}\text { Resident } \\
40 \mathrm{kgP} / \mathrm{ha}\end{array}$ & $\begin{array}{c}\text { Wana } \\
40 \mathrm{kgP} / \mathrm{ha}\end{array}$ \\
\hline Jul & 10 & 12 & 15 & 20 \\
Aug & 11 & 16 & 16 & 21 \\
Sep & 22 & 30 & 26 & 35 \\
Oct & 30 & 34 & 35 & 40 \\
Nov & 32 & 36 & 35 & 40 \\
Dec & 30 & 30 & 28 & 35 \\
Jan & 22 & 25 & 28 & 30 \\
Feb & 20 & 21 & 23 & 25 \\
Mar & 18 & 20 & 20 & 22 \\
Apr & 15 & 20 & 16 & 20 \\
May & 11 & 16 & 15 & 18 \\
Jun & 10 & 14 & 12 & 16 \\
\hline Annual total & 7022 & 8330 & 8263 & 9781 \\
\hline
\end{tabular}

\section{Results and discussion}

\section{Pasture type}

Consistent with previous studies (Barker et al. 1985, 1993), pasture growth during 13 June 1997 to 14 May 1999 averaged $31 \%$ greater on Wana pastures than for resident pastures with the response being greatest during winter (Table 1). Since Wana pastures only contributed to half the farmlet area, the benefit to Wana farmlets was halved (15\%). During 1997-98, although the stocking rate of Wana farmlets was $6 \%$ greater than Resident farmlets, bulls had similar liveweight between pasture types (Figure 1). Farmlets were also grazed with sheep and cows during autumn. In 1997-98, this grazing averaged $3.9 \mathrm{SU} / \mathrm{ha}$ on Wana farmlets and 3.5 SU/ha on Resident farmlets. During 1997-98 the Wana farmlets generated an average $\$ 42.80 /$ ha greater income than Resident farmlets. This was similar to the average \$39.18/ha greater income from Wana farmlets than Resident farmlets for the previous 4 years, and shows the relevance of the result presented for $1997-$ 98.

At the level of financial return measured, and for a cost of $\$ 138 /$ ha of system developed ( $\$ 275 /$ ha oversown), $8 \%$ interest on capital and $\$ 60 /$ ha for grazing costs in the establishment winter, the period to breakeven financially from Wana cocksfoot oversowing was 8 years. This was an almost identical result to a similar calculation by Parminter (1991).

\section{Fertiliser}

The fertiliser treatments resulted in a gradient of $\mathrm{P}$ status, with 0,20 , and $40 \mathrm{~kg} \mathrm{P} /$ ha resulting in an Olsen $\mathrm{P}$ status of $17.9,24.2$ and $29.5 \mu \mathrm{P} / \mathrm{g}$ soil in October 1997. The pasture yield response to added $P$ averaged $51 \mathrm{kgDM} / \mathrm{kgP}$. This was similar to $44,55,78 \& 91$ $\mathrm{kgDM} / \mathrm{kgP}$ reported by Ledgard et al. (1992), Gillingham et al. (1990), O'Connor et al. (1990), Lambert et al. (1983), respectively. The larger responses were from longer-term trials where fertiliser from previous years contributed to the measured response. There was no statistically significant interaction between pasture type and fertiliser level, showing that Wana and resident pastures had a similar response to superphosphate. 


\section{Modelling}

Stockpol was able to model the Wana and Resident bull systems, with a good agreement between the measured and modelled data. On average, modelling with Stockpol found gross financial return was increased by $\$ 67 /$ ha by establishment with Wana cocksfoot (Table 3), this was similar to the $\$ 42.30$ actually observed. No adjustment was made for pasture quality, since Wana- and browntop-based pastures have similar quality (Barker \& Baars 1993).

On average, modelling with Stockpol found gross financial return was increased by $80 \%$ by application of $40 \mathrm{kgP} / \mathrm{ha}(\$ 715.26 / \mathrm{ha})$ compared to nil fertiliser (\$397.84/ha) (Table 3). With a cost of fertiliser of \$2.44/ $\mathrm{kgP}$ applied (\$97.60) this predicted return was highly profitable.

\section{Conclusion}

Investment in either Wana cocksfoot establishment or fertiliser application resulted in a net financial benefit. In the case of Wana cocksfoot, biological responses did not occur until the second year after investment (establishment) and if the costs of interest were included, the cash investment was not returned until 8 years. Wana pastures are known to persist for 20 years so financial benefits would continue beyond the 'breakeven' period. Among the benefits to Wana establishment was greater management flexibility in being able to finish animals to $500 \mathrm{~kg}$ liveweight sooner than for resident pastures. There are significantly greater risks of establishment failure in the establishment period than in obtaining the observed fertiliser response. If the establishment costs of Wana could be spread over the life of the pasture, economic responses would be greater from investment in Wana cocksfoot, however, in the short term, economic responses were greater from investment in fertiliser. In the medium term a combination of investment in Wana establishment and fertiliser input would likely maximise the economic return.

\section{ACKNOWLEDGEMENTS}

Contribution from J. Napier, Ballantrae Farm staff, the AgResearch Grasslands Herbage Lab, H. de Latour, J. Langdon, A. Milne, M. Plowman, G. Thomas, M. Cammock and N. Heath is acknowledged. Meat New Zealand funded this project (96PR 41/3.3) during 19961999.

\section{REFERENCES}

Barker, D.J.; Lancashire, J.A.; Meurk, C. 1985. 'Grasslands Wana' cocksfoot - An improved grass suitable for hill country. Proceedings of the New Zealand Grassland Association 46: 167-172.

Barker, D.J.; Baars, J.A. 1993. Comparing the seasonal productivity of cocksfoot and resident pastures on hill country farms using a system-model. Proceedings of the New Zealand Grassland Association 55: 81-85.

Barker, D.J.; Lambert, M.G.; Dymock, N.; Gray, Y.S. 1993. Introduction, production and persistence of five grass species in dry hill country 5. Central Wairarapa. New Zealand journal of agricultural research 36: 29-39.

Clark, D.A.; Lambert, M.G.; Grant, D.A. 1986. Influence of grazing and fertiliser management on North Island moist hill country. 5. Animal production. New Zealand journal of agricultural research 29: 407420.

Gillingham, A.G.; Richardson, S.; Power, I.L.; Riley, J. 1990. Long-term effects of withholding phosphate application on North Island hill country: Whatawhata Research Centre. Proceedings of the New Zealand Grassland Association 51: 11-16.

Lambert, M.G.; Clark, D.A.; Grant, D.A.; Costall, D.A. 1983. Influence of grazing and fertiliser management on North Island moist hill country. 1. Herbage accumulation. New Zealand journal of agricultural research 26: 95-108.

Ledgard, S.F.; Thorrold, B.S.; Sinclair, A.G.; Rajan, S.S.S.; Edmeades, D.C. 1992. Summary of eleven long-term field trials with 'Longlife' phosphatic fertiliser. Proceedings of the New Zealand Grassland Association 54: 35-40.

Marshall, P.R. 1991. Stockpol: A decision support model for livestock farms. Proceedings of the New Zealand Grassland Association 53: 137-140.

O'Connor, M.B.; Smart, C.E.; Ledgard, S.F. 1990. Longterm effects of withholding phosphate application on North Island hill country: Whatawhata Research 
Centre. Proceedings of the New Zealand Grassland Association 51: 21-24.

Parminter, T.G. 1991. Financial evaluation of hill pasture improvement. Proceedings of the New Zealand Grassland Association 53: 117-121.

Webby, R.W.; Sheath, G.W.; Boom, C.J. 1990. Performance of new pasture cultivars in a hill country finishing system. Proceedings of the New Zealand Grassland Association 51: 151-156. 
